\title{
CRITICAL PEDAGOGY AND NEOLIBERALISM
}

\author{
PEDAGOGIA CRÍTICA E NEOLIBERALISMO \\ PEDAGOGÍA CRÍTICA Y NEOLIBERALISMO
}

Katie Fitzpatrick*, Darren Powell*

\begin{abstract}
Keywords:
Physical Education.

Health education.

Critical pedagogy.

Neoliberalism.

Abstract: In this article, we reflect on the possibilities and responsibilities of critical pedagogy in relation to neoliberalism and physical education. In exploring these ideas, we also discuss problems of definition, such as the collapse and confusion of terms like critical pedagogy, critical research, and critical health and PE, as well the problematic positioning of 'neoliberalism' in critical scholarship. Although there is a growing body of research that illuminates the nuances and pervasiveness of neoliberal HPE policies and practices - both globally and in specific social contexts - we argue that there is still more work to be done to identify how critical pedagogical work may address (or at least attend to) the effects of neoliberalism. After all, there remains a 'danger' that critical pedagogy in neoliberal times may forward, rather than contest, the worst effects of neoliberal schooling and neoliberal HPE.
\end{abstract}

Palavras chave: Educação Física. Educação em saúde. Pedagogia crítica. Neoliberalismo.

Resumo: Neste artigo, nós refletimos sobre as possibilidade e responsabilidades da pedagogia crítica em relação ao neoliberalismo e a Educação Física. Ao explorar essas ideias, nós também discutimos os problemas da definição, bem como o colapso e confusão de termos como pedagogia crítica, pesquisa crítica e saúde crítica e Educação Física, bem como a problemática posição do neoliberalismo nos estudos críticos. Embora exista um crescente corpo de pesquisas que iluminam as nuanças e onipresença das políticas e práticas neoliberais em HPE - tanto em contextos globais e em contextos sociais específicos - nós argumentamos que ainda existe mais trabalho a ser feito para identificar como o trabalho pedagógico crítico pode dirigir-se (ou ao menos tentar) aos efeitos do neoliberalismo. Ao fim, continua a existir o perigo de que a pedagogia crítica em tempos neoliberais possa transmitir, em vez de contestar, os piores efeitos da escolarização neoliberal e do neoliberalismo em saúde e Educação Física.

Resumen: En este artículo, reflexionamos sobre las posibilidades y las responsabilidades de la pedagogía crítica en relación al neoliberalismo y la Educación Física. Además de explorar estas ideas, debatimos los problemas de la definición, así como el colapso y la confusión de los términos como pedagogía crítica, investigación crítica, salud crítica y Educación Física, así como la problemática del neoliberalismo en los estudios críticos. Si bien hay un creciente cuerpo de investigaciones que iluminan los matices y la omnipresencia de las políticas y practicas neoliberales en HPE - tanto en los contextos globales como sociales específicos - nosotros argumentamos que ha todavia más trabajo por hacer para identificar como el trabajo pedagógico puede dirigirse (o por lo menos intentar) a los efectos del neoliberalismo. Al ultimo, sigue existiendo el peligro de que la pedagogía crítica en tiempos neoliberales pueda transmitir, en lugar de cuestionar, los peores efectos de la escolarización neoliberal y del neoliberalismo en salud y Educación Física.
*The University of Auckland. Auckland, New Zealand.

E-mail: k.fitzpatrick@auckland.ac.nz; d.powell@auckland.ac.nz

Received 06 June 2019

Accepted 23 September 2019 Published 15 November 2019

DOI: hitps://doi.org/10.22456/1982-8918.96638 (c) (1) (8) Licence 


\section{INTRODUCTION}

This article is something of a thought piece about the connections and contentions of critical pedagogical work in health and physical education (HPE), and concurrent debates about neoliberalism. We observe that critical pedagogy is having something of a resurgence in HPE in current times, and we reflect on whether proponents are aligned in their thinking in this regard, or not. Importantly, we wonder whether critical pedagogical approaches to HPE that focus on broad (or vague) research agendas, or those that focus exclusively on the politics of representation, might remain naïve to the insidious and devastating erosion of public good education in neoliberal times. In exploring these ideas, we discuss problems of definition (about critical research and critical pedagogy; health and PE and 'HPE', and whether we are talking about the same thing when we talk about neoliberalism). We end with some thoughts about the possibilities for critical pedagogy within rampant neoliberal contexts, and ask whether critical pedagogy is, in fact, in danger of reproducing rather than contesting the worst effects of neoliberal schooling.

\section{WHAT ARE WE TALKING ABOUT WHEN WE TALK ABOUT CRITICAL PEDAGOGY IN HPE?}

Critical pedagogical writings in health and physical education seem to be having something of a 'moment' in the field. Even scholars who have previously ignored or critiqued critical pedagogy seem to be joining the party and making claims about the potential for critical pedagogical work. Why is this? One explanation concerns the history of critical scholarship in the field, and the strong trajectory of work focused on exposing issues of inequity, injustice, power and politics (DAGKAS; ARMOUR, 2012; ROBINSON; RANDALL, 2016; WRIGHT; BURROWS; MACDONALD, 2004). While this work has challenged the field in significant ways, it does make for depressing reading for those interested in making change. Critical pedagogies, focused as they are on practice, are (potentially) rather more optimistic in offering some kind of response to such issues. However, we do wonder here and reflect on the possibilities and responsibilities of critical pedagogy in relation to neoliberalism. A great deal of critical work in the field considers neoliberalism and its impacts for health and PE (EVANS; DAVIES, 2014; EVANS; DAVIES, 2015; EVANS; DAVIES, 2017; MACDONALD, 2015; POWELL, 2020). With Kirk's (2020) new book as an exception, little of the work in PE critical pedagogy, however, considers the direct implications of neoliberal environments on what might be possible pedagogically and politically. In this, we wonder whether critical pedagogical work that does not address (or at least attend to) neoliberal environments can actually make the kind of differences that are claimed for it. In the introduction to their edited book, Pringle, Gerdin and Larsson (2018) even "dismiss the view that if critical research aims to make a real difference then the focus should be specifically on overtly political issues such as neoliberal capitalism or the growth of the precariat class". Instead, they suggest that critical research can make a difference in a range of ways to power relations. In this, they assume that research itself can make a difference (to practice, one assumes), a claim that is highly contestable and perhaps naïve to the importance of the very historical and political contexts which produce inequities. The problem here is that the terminology of critical pedagogy, critical research, and critical health and PE get rather confused and collapsed. While some - like Pringle et al. (2018) - seem to be arguing that critical research itself might make a difference, the difference itself is unclear. Evans and Davies (2014, p. 869), rather, argue that: 
Our analyses suggest that research attention to the politics of identity, essentially, how pupils are positioned within institutions in 'relation to' various discourses, cultures and values given by the curriculum, pedagogical and assessment practices of schooling and Initial Teacher Education Physical Education (ITEPE) is a necessary but insufficient research agenda if the profession's project is social justice and pursuit of democratic ideals.

They go on to question the limited focus on the politics of identity that has dominated critical HPE research, and argue for greater attention to political economy, neoliberal environments and the rapid privatisation of public education.

Others argue for a much greater focus on pedagogies within critical work (ENRIGHT; O'SULLIVAN, 2010; ENRIGHT; O'SULLIVAN, 2013; FITZPATRICK, 2013). Indeed, Kirk (2020) argues that, if we intend to make change in the field, then "A first priority in formulating a new critical pedagogy for physical education is to sharpen its focus on pedagogy". We agree and also contend that pedagogy must attend directly to the political, including the education landscapes that Evans and Davies $(2014,2015,2017)$ highlight.

It is worthwhile here to take a moment to consider the various definitions that we are working with, and how critical pedagogy might be conceptualised in relation to health and physical education. When we are discussing 'health and physical education', we are, in fact, talking about two different, overlapping fields: health education and physical education. This is how health and PE (or HPE) is defined and treated in the context we are in, Aotearoa New Zealand. We are very aware that HPE does not necessarily include health education (as the study of health) in other national and cultural contexts. Sometimes the term 'HPE' is used to actually just mean physical education, or to denote an undefined relationship between PE and some kind of health agenda. It can mean 'PE and some aspects of health' (usually nutrition) and/or ' $P E$ for health'. In some countries HPE is the name of the curriculum area and is reflected in official policy (such as in New Zealand and Australia), while in others health is positioned as an aspirational outcome of engaging in PE. For us, health education is a subject in its own right (in curriculum, in policy and in practice in schools and university settings) and so HPE stands for: health education and physical education (with the 'education' relating to both). Critical pedagogy then has a different history in health education than it does in physical education (FITZPATRICK; BURROWS, 2017; GARD; LEAHY, 2009; KIRK; TINNING, 1990; KIRK, 2010; KIRK, 2020; LEAHY et al., 2016). In physical education, critical pedagogy can be defined along wildly different lines and Kirk (2020) observes that: "Critical pedagogy has become, like physical education itself, a contested concept [....] although this contested notion is closely associated with social justice" . Kirk (2020) also argues that:

Critical pedagogy more specifically is concerned with the organization and alignment of curriculum, teaching, learning and assessment in ways that render physical education inclusive, fair, and equitable as an embodied experience for young people .... Through this experience, critical pedagogy seeks to empower young people.

The notion of empowerment is perhaps contestable in light of poststructuralist thinking that power cannot be possessed by or liberated from individuals, but is omnipresent, unpredictable, inseparable from knowledge, and works its way through the entire social body through social interactions (FOUCAULT, 1977, 1980). However, Kirk's (2020) focus on inclusion, fairness and equity, and the potential for critical pedagogies to 'dispose' young people "[...] to question the 
taken for granted, to care about injustice and unfairness, for themselves and others, to be bothered to take action", aligns with the concerns of many in the field. (DAGKAS; ARMOUR, 2012; FELIS-ANAYA; MARTOS-GARCIA; DEVÍS-DEVÍS, 2018; MCCUAIG; ENRIGHT; ROSSI; MACDONALD; HANSEN, 2016; PRINGLE et al., 2018; ROBINSON; RANDALL, 2016; WRIGHT et al., 2004).

In their critical scholarship, Evans and Davies (2015) insist, however, that critical approaches to physical education (as well as those that are radical, inclusive, or innovative) may well lack legitimacy "in an educational market where social justice is not the primary concern" (p. 3; their emphasis). And so, scholars are somewhat divided over whether critical pedagogy is possible, what it might do and be, and whether the focus should be on the politics of identity (Robinson \& Randall, 2016), critical research of any kind (Pringle et al., 2018), or a deeper and more located politics that contests, not only located relations of power, but wider sociohistorical educational landscapes (EVANS; DAVIES, 2014; EVANS; DAVIES, 2015; EVANS; DAVIES, 2017; KIRK, 2020). Such debates here might well benefit from engagement with concurrent debates in the field of health education and we contend that it is worth considering how critical pedagogy, in the aligned - but distinct - field of health education, is currently being defined.

In a recent article, Fitzpatrick, Leahy, Webber, Gilbert, Lupton and Aggleton (2019, p. 4) define critical health education in the following way:

Critical health education then destabilises the usual calls to behaviour change and morality and aims to liberate health educators from the impossible task of becoming saviours. Instead, health education itself becomes a subject of study (Fitzpatrick \& Tinning, 2014). This necessarily includes knowledge across the disciplines of epidemiology, human biology, biomedical health as well as health sociology, interpersonal communication, and work in the fields of race, class, gender and sexuality, mental health, food studies, fat studies, nutrition, body studies, and so forth. Each of these different constellations of knowledge and inquiry can be brought to bear on key health issues and concerns, so that students of health education can engage with the myriad of uncertain and contested knowledges in the field. (emphasis in original)

Critical pedagogy in health education then concerns pedagogical work that values health education as a subject of study, that draws on diverse disciplinary knowledge, but which is also concerned with exposing the historical and political trajectories of such knowledge. This is an epistemological move that refuses health education as an intervention into social justice (or health problems) and rather situates health education as a subject of study that is itself "[...] positioned historically, in relations of power and within hierarchies" (FITZPATRICK, 2019, p. 4). Fitzpatrick (2019) further argues that physical education might learn from these parallel debates and observes that:

Critical research [in physical education] takes an approach inspired by histories of critical thought, coupled with post-structuralism. The argument here is that people are immersed within political and cultural contexts that frame their possibilities, and ... within complex relations and networks of power that create subjectivity and limit or allow possibilities. The intentions here are to show how such relations of power are deeply historical and implicate practice, people, and environments, and how PE often has affects that are unintended but unavoidable because teachers, students and schools are all located in cultural contexts and social hierarchies at the intersections of gender, race, ethnicity, social class, location, abilities, body size and sexualities. (FITZPATRICK, 2019, p. 4) 
This is an approach to critical physical education that combines both concerns about identity, and attention to wider politics. So, if critical pedagogy must by necessity take account of the historical in a poststructuralist sense then neither will simply doing critical research make a 'difference', nor can teachers directly address relations of power without attending to the sociohistorical and political. In this sense, one might argue that neoliberalism and capitalism cannot but be part of the critical pedagogical in health education and PE. We consider now what neoliberalism actually means in education broadly, and in HPE contexts more particularly.

\section{WHAT DO WE MEAN BY NEOLIBERALISM?}

In his book Global education inc.: new policy networks and the neo-liberal imaginary, Ball (2012) asserts that 'neoliberalism' needs to be used with much caution, as "[l]t is one of those terms that is used so widely and so loosely that it is in danger of becoming meaningless" (p. 3). In some circles, it has been employed as a catch-all phrase to signal the deleterious effects of globalisation and privatisation, including social injustice, economic inequality, and the marginalisation of people and populations based on ethnicity, social class, gender, sexuality, body size, and (dis)ability (amongst others). This, however, can become a shallow form of argumentation that enables authors to quickly come to the certain conclusion that, quite simply, 'neoliberalism did it'.

We do not have space here to describe the history of (neo)liberal modes of government, the different phases of neoliberalism (e.g. 'proto neoliberalism', 'roll-back neoliberalism', 'roll out neoliberalism'; (PECK; TICKELL, 2002) or diverse theoretical perspectives. However, like a number of authors before us (BALL, 2012; CLARKE, 2008; EVANS, 2014), we argue that the need to be both cautious and rigorous when using the ' $N$ ' word as it has become "[...] so commonly understood that no further or deeper explanation is required; the belief that neoliberalism exists and that it has impacted on the field of education 'does not think of itself as a belief' (BOURDIEU, 1998, p. 81) but goes 'without saying' (BOURDIEU, 1998, p. 113)" (ROWLANDS; RAWOLLE, 2013, p. 268). In the field of PE it is a similar story. Gard (2015) points out that if researchers truly wish to challenge social injustices in or with $\mathrm{PE}$, then we need to interrogate our own assumptions about (neoliberal) PE: "If we already 'know' neoliberalism and its policy foot soldiers are anathema to people living 'decent lives' then there really is no point spending time researching or discussing these phenomena" (p. 115). In some ways, perhaps we too have fallen into the rhetorical and theoretical 'trap' of assuming, as our starting point for this paper, that neoliberalism has, and will continue to, undermine and subjugate the critical project. In other ways, however, Gard's warning provides us with a strong reminder of the necessity for researchers to challenge our own assumptions and, at the same time, provide more nuanced critical examinations of the diverse modes, practices, policies, pedagogies, and discourses that shape PE, including those underpinned by neoliberal political rationalities.

In this vein, it is important to provide some framing around how we define neoliberalism and how it relates back to PE and the critical project. Drawing on Coakley's (2011, p. 69) analysis of neoliberalism and sport, we argue that neoliberalism may be established in four distinct, yet interrelated, ways:

(1) as an economic doctrine, (2) as a political project, (3) as a cultural perspective, and (4) as a guide for the organization of social relationships. In sociological terms, neoliberalism is a web of ideas and beliefs that identifies a combination of 
free markets, political deregulation and privatization, individual self-interest, and inequality as the foundation for progress and all forms of development.

As Coakley (2011) demonstrates, these four manifestations of neoliberalism are based on key assumptions and draw on dominant discourses. As an economic doctrine, free markets are considered to be the best means to drive all forms of progress, including economic and social progress. As a political project, neoliberalism places an emphasis on the deregulation of markets (national, global and transnational), reducing the role of the state (but at the same time ensuring the state continues to create and maintain private sector interests), privatising the public sector, and eliminating collectives - all with the aim of restricting the states' ability to 'interfere' with free market principles. As a cultural perspective, neoliberalism works to promote the idea that 'big government' is dangerous, that processes of privatisation are more efficient and effective than the bureaucratic public sector, and that market forces combined with increased individual responsibility will enable individuals to be more responsible and successful (with the assumption that individual failure can be put down to individual irresponsibility, immorality and poor choices, rather than the failure of the market). Finally, neoliberalism acts as a framework for organising social relationships by rewarding competition, creating 'winners' and 'losers' (including rich and poor), and by ensuring individual and collective subjectivities are aligned with principles of the free market (e.g. students and parents as consumers; schools as businesses). In these ways, "competition, inequality, and hierarchical forms of organization are viewed as normal aspects of social relationships and accepted as proof of fairness, meritocratic processes, and progress" (COAKLEY, 2011, p. 73).

The 'neoliberal turn' "has called into question the very aims and purposes of public education" (CODD, 2008, p. 15). The democratic goals of public education have been eroded as education as a social good being pervasively conflated with education as a "corporate good" (SALTMAN, 2011, p. 13). Neoliberalism has, and continues to, reduce the role of the state by aligning education more closely with key tenets of neoliberalism, including autonomy, competition, freedom of choice, enterprise and entrepreneurialism, standardisation, performance, individual responsibility, commercialisation, privatisation, and consumption (BALL, 2012; BOYLES, 2008; POWELL, 2020; SALTMAN, 2010). The impact of neoliberalism is not only felt at the level of policymaking, but in specific curriculum areas (KIRK, 2020) and by teachers and students. As Powell $(2019$, p. 380) argues: "the responsibility of public education to promote critical citizenship has been 'assaulted' by corporations for the development of profit, eroding the ability of teachers to prepare students to participate as democratic citizens". This is certainly the case with PE in schools, and although there are important differences in the extent and effects of corporatisation between various geographic and socio-cultural contexts. For examples, see the 2014 special edition of Physical Education and Sport Pedagogy (MACDONALD, 2014), there is undoubtedly a plethora of private sector players that continue to shape PE, schools, teachers, and students across the globe (POWELL, 2020).

It is also vital to point out that neoliberalism in education is not necessarily a top-down form of power 'done onto' powerless teachers and students by governments, nor is it a simple or straightforward process of rampant privatisation or individualisation driven by unscrupulous corporate players. As an ideology, neoliberalism "works on and in public sector institutions, and on and in the state .... realised, disseminated and embedded" (BALL, 2012, p. 15) through newly developed quasi-markets, entrepreneurialism, and the increasingly blurred boundaries between 
public, private and voluntary sector organisations (POWELL, 2019). Neoliberalism is messy, complex, and unpredictable. However, the 'triumph' of the "neoliberal imaginary" (BALL, 2012, p. 66) is demonstrated by the normalisation, or at times celebration, of neoliberal PE practices and policies, especially those that (un)wittingly promote "'market-based solutions' to 'wicked' social and educational problems" (p. 66), such as obesity, physical inactivity, and other PErelated 'crises' (KIRK, 2006; THORPE, 2003). It may be further evidenced by the unwillingness of PE researchers and practitioners to critique 'our' own complicity in the neoliberal project (EVANS, 2014).

Although there are particular elements of neoliberalism that appear to traverse many national contexts (e.g. outsourcing of curricula) and repeated patterns of how PE is rationalised and operationalised (e.g. emphases on attending to public health imperatives and producing 'responsible' citizens), there are also important nuances that need to be examined, including how neoliberalism 'works' in different schools, communities, and diverse socio-cultural contexts. As Shamir (2008) reminds us, neoliberalism is a complex, contradictory, unstable, and incoherent rationality of government (SHAMIR, 2008); one that is constantly shifting and morphing. It is a highly adaptable ideology with an "ongoing dynamic of discursive adjustment, policy learning, and institutional reflexivity" (PECK; TICKELL, 2002, p. 392). In this way, the impact of the neoliberal project (or projects) is rarely homogenous, uniform, predictable, or totalising. It be cannot be considered simply, or inherently, 'good' or 'bad'. As Powell (2015b) observed in his research on the corporatisation of health and physical education in primary schools in New Zealand, although some teachers and school leaders were apathetic to certain neoliberal forms of education (e.g. outsourcing HPE teaching to external providers), others were vehemently opposed to more obvious neoliberal reforms (e.g. outsourcing of teachers' payroll, the prospect of performance-based pay, introduction of National Standards). Furthermore, even though students were frequently experiencing 'neoliberal' PE lessons (that were often highly corporatised and commercialised), this did not necessarily 'force' students to become

[...] corporate stooges who uncritically reproduced dominant notions of health, fatness, and consumerism. A number of children and teachers actively contested the multifarious discourses and discursive practices. Indeed, one of the most encouraging and rewarding aspects of my research was that children were perhaps the most critical out of all the participants I worked with. (POWELL, 2015b, p. 217, emphasis in original)

Evans (2014, p. 546) further reminds us that when investigating and interrogating global processes, such as the relationships between neoliberalism and PE policymaking, we must be thoughtful and cautious when making generalisations:

\begin{abstract}
[...] teachers, pupils and other education personnel are not cultural dupes or dopes or mere conduits of policy. There is ... limited linearity between global imperatives, whether of neoliberal or other ideological kinds and their enactment in schools and wider socioeducational contexts. Global imperatives relating to PE, sport and health (e.g. seeking to foster more participation, more physical activity or helping people lose weight) do not produce uniform outcomes or homogeneity of practice across continents and countries. Between the enunciations of an imperative, its enactment as policy and, possible enactment as pedagogic practice, rest a host of complicating and confounding factors.
\end{abstract}

There is a growing corpus of research that sheds light on the intricacies, pervasiveness, and 'dangerousness' of neoliberal HPE policies and practices - both globally and in specific social 
contexts (EVANS; DAVIES, 2015; GARD; PLUIM, 2014; KIRK, 2020; MACDONALD, 2014; MACDONALD; HAY; WILLIAMS, 2008; MCCUAIG et al., 2016; PENNEY; PETRIE; FELLOWS, 2014; POWELL, 2020; SPERKA, 2018; WILLIAMS; MACDONALD, 2014). However, there is still more work to be done. We share Evans and Davies (2017, p. 688) concern that:

\begin{abstract}
All too rarely has research in PE, health and sport (ours included) reported on issues of distribution ... or of governance, or how individuals and/or populations gain access to particular schools of different sorts, or the educational opportunities within and between them, or the differential distributions of human and economic resource to PE, health and sport across and within educational sectors. Yet, given the socio-political world we now inhabit, now more than ever, attention to both the political economy of education and cultural politics is required if the effects of new Right politics and conservative populism on PE, teachers, pupils, parents, families and others with vested educational interests are to be systematically explored and better understood.
\end{abstract}

This is, of course, a difficult and complicated task; one that necessitates continued vigour, focus, and the employment of diverse theoretical and methodological tools. Evans (2014, p. 554) cautions that we need to think beyond the call "for more 'critical reflection' or more "critical pedagogy"' in schools, not because these are necessarily ineffective or unimportant, but because they do not appear to change the unequal, unfair, and unjust power relations that operate outside of the classroom. While we agree that simply 'more' critical pedagogy is unlikely to be effective, we argue that critical pedagogy can provide spaces that are counter-hegemonic, actively work to resist neoliberalism in PE (as well as education and society more broadly), and importantly, pay serious "attention to those base, structural conditions and inequalities upon which social and cultural injustices and improprieties depend for their very existence" (EVANS; DAVIES, 2017, p. 686).

\title{
4 SO, WHAT OF CRITICAL PEDAGOGY AND NEOLIBERALISM?
}

In this final section, we reflect on whether critical pedagogy in HPE does have legitimacy in light of neoliberal educational environments, and if it does, what a response might be. It is possible to take heart from those who view neoliberalism as less of a monster than might be presumed from our discussion above, and perhaps as an opportunity. McCuaig et al (2016, p. 153), for example, suggest that: "The intersection of neoliberalism and HPE may not necessarily be detrimental to equitable HPE practices or student engagement", although go on to assert there is "evidence at the macro (inter/national) and micro (classroom) levels that neoliberal priorities ... can produce inequitable practices and perpetuate inequities". Macdonald (2015), somewhat troublingly, argues that the language and techniques of neoliberalism might be adopted to reimagine teachers as 'knowledge brokers' in contemporary schools. This argument puts the emphasis back on the agency of teachers to contend with the demands of edubusiness, privatisation, and neoliberal education reforms. Likewise, Hogan et al. (2018, p. 627) conclude that "teachers are not being seduced by commercialisation, but are often discerning actors in the schooling marketplace". These arguments might be compelling and received as a move against the totalising discourse of neoliberalism and the (potential) hopelessness it engenders. However, while pragmatic, these arguments are problematic in that they seem to offer a diluted response to neoliberalism and one that also buys into neoliberalism through its attention to individual responsibility (and blame), teacher agency, and, ultimately, an acceptance of education 
and schooling as another 'market'. Evans (2014, p. 554) laments how the PE profession has unintentionally co-opted neoliberal notions of individualism through efforts to equalise and enhance "sensitive subjectivities so that everyone thinks more positively about each other (and others' cultures) (no bad thing of course) further helping to "validate that of neoliberalism itself and become part of its vernacular, while posing little threat or challenge to the structural socioeconomic conditions that it thrives on". But, is critical pedagogy actually any kind of antidote to neoliberalism in HPE, or is it a cry in the wilderness against forces it has no chance of competing with, let alone contesting in any real way? It is worth considering in relation to this question what has happened to PE, and to HPE, in current (neoliberal) times, and whether these trends in the field might be a place to begin any kind of unravelling of neoliberalism in the field. For example, the health agenda - which we differentiate here from health education - in physical education has had an invidious effect on the field in recent times. We suggest here that this might be one place for critical pedagogues of HPE to begin to challenge the worst kinds of neoliberalism in the field.

While physical education has never been free of moralistic and health-related practices of various kinds, the obesity epidemic discourse has re-positioned physical education as a healthrelated practice in unprecedented ways (EVANS, 2003; GARD; WRIGHT, 2005; GARD; PLUIM, 2014; KIRK, 2006; POWELL, 2020). This move has simultaneously positioned physical education as a hyper-neoliberal practice of body maintenance, control and individual responsibility, and also relegated health (education) as far as possible from an educative undertaking and instead as a desirable product of engaging in physical activity. This, indeed, might be a place for critical pedagogy to begin: to uncouple physical education from health-related doctrines, and instead rediscover it away from health outcomes and (back) towards education. We take heart in this from Enright, Alfrey and Rynne's (2017) discussion of neoliberalism in the academy, in which they note that the very notion of (or study of) the neoliberal university suggests that there are other, different, kinds of university that are possible (and that have both existed historically and could do again). There are certainly many such versions of physical education and HPE, and we might remember and (re)imagine what physical education and HPE 'is' - both without and against neoliberalism.

\section{REFERENCES}

BALL, Sthepen J. Global education inc.: new policy networks and the neoliberal imaginary. Oxon, UK: Routledge, 2012.

CLARKE, John. Living with/in and without neo-liberalism. Journal of Global and Historical Anthropology, v. 51, p. 135-147, 2008. doi: https://doi.org/10.3167/fcl.2008.510110

COAKLEY, Jay. Ideology doesn't just happen: sports and neoliberalism. Revista da Associación Latinoamericana de Estudios Socioculturales del Deporto, v. 1, n. 1, p. 67-84, 2011.

CODD, John. Neoliberalism, globalisation and the deprofessionalisation of teachers. In: CARPENTER, Vick, J (Eds). Nga Kaupapa here: connections and contradictions in education. Melbourne: Cengage Learning, 2008. p. 14-24. 
DAGKAS, Symeon; ARMOUR, Kathleen. Inclusion and exclusion through youth sport. Oxon, UK: Routledge, 2012.

ENRIGHT, Eimear; ALFREY, Laura. RYNNE, Steven Being and becoming an academic in the neoliberal university: A necessary conversation. Sport, Education and Society, v. 22, n. 1, p. 1-4, 2017. doi: 10.1080/13573322.2016.1259999

ENRIGHT, Eimear; O'SULLIVAN, Mary. "Can I do it in my pyjamas?": Negotiating a physical education curriculum with teenage girls. European Physical Education Review, v. 16, n. 3, p. 203-222, 2010.

ENRIGHT, Eimear; O'SULLIVAN, Mary. "Now, I'm magazine detective the whole time": Listening and responding to young people's complex experiences of popular physical culture. Journal of Teaching in Physical Education, v. 32, n. 4, p. 394-418, 2013.

EVANS, John. Physical Education and health: a polemic or let them eat cake! European Physical Education Review, v. 9, n. 1, p. 87-101, 2003. doi: https://doi. org/10.1177/1356336X03009001182

EVANS, John. Neoliberalism and the future for a socio-educative physical education.

Physical Education and Sport Pedagogy, v. 19, n. 5, p. 545-558, 2014. doi: $\underline{10.1080 / 17408989.2013 .817010}$

EVANS, John; DAVIES, Brian. Physical education PLC: Neoliberalism, curriculum and governance. New directions for PESP research. Sport, Education and Society, v. 19, n. 7, p. 869-884, 2014. doi:10.1080/13573322.2013.850072

EVANS, John; DAVIES, Brian. Physical education, privatisation and social justice. Sport, Education and Society, v. 20, n. 1, p. 1-9, 2015. doi:10.1080/13573322.2014.942624

EVANS, John; DAVIES, Brian. In pursuit of equity and inclusion: Populism, politics and the future of educational research in physical education, health and sport. Sport, Education and Society, v. 22 , n. 5, p. 684-694, 2017. doi:10.1080/13573322.2017.1307176

FELIS-ANAYA, Mercè; MARTOS-GARCIA, Daniel; DEVÍS-DEVÍS, José. Socio-critical research on teaching physical education and physical education teacher education: a systematic review. European Physical Education Review, v. 24, n.3, p.314-329, 2018.

FITZPATRICK, Katie. Critical pedagogy, physical education and urban schooling. New York, NY: Peter Lang, 2013.

FITZPATRICK, Katie. What does HPE do for the world? considering critical pedagogies and beyond. Long Island: New York, 2019.

FITZPATRICK, Katie; BURROWS, Lisette. Critical health education in Aotearoa New Zealand. Sport, Education and Society, v. 22, n. 5, p. 552-568, 2017. doi: $\underline{10.1080 / 13573322.2015 .1131154}$

FITZPATRICK, Katie et al. Critical health education studies: reflections on a new conference and this themed symposium. Health Education Journal, v. 78, n.6, p.621-632, 2019. doi:10.1177/0017896919860882.

FOUCAULT, Michel. Discipline and punish: the birth of the prison. New York: Pantheon Books, 1977. 
FOUCAULT, Michel. Power/knowledge: selected interviews and other writings 1972-1977. London: Harvester Press, 1980.

GARD, Michael. 'They know they're getting the best knowledge possible': Locating the academic in changing knowledge economies. Sport, Education and Society, v. 20, n. 1, p. 107-121, 2015. doi: https://doi.org/10.1080/13573322.2014.957177

GARD, Michael; LEAHY, Deana. Dicing with death: Tensions, contradictions and awkward positions in school health education. In: DINAN-THOMPSON, Maree. Health and physical education: issues for curriculum in Australia and New Zealand. Melbourne: Oxford University, 2009. p. 183-197.

GARD, Michael; PLUIM, Carolyn. Schools and public health: past, present, future. Maryland, USA: Lexington Books, 2014.

GARD, Michael; WRIGHT, Jan. The obesity epidemic: science, morality, and ideology. New York: Routledge, 2005.

HOGAN, Anna et al. Nuancing the critique of commercialisation in schools: recognising teacher agency. Journal of Education Policy, v. 33, n. 5, p. 617-631, 2018. doi:10.1080/02680939.2017. $\underline{1394500}$

KIRK, David. The obesity crisis and school physical education. Sport, Education \& Society, v. 11, n. 2, p. 121-133, 2006. doi: $10.1080 / 13573320600640660$

KIRK, David. Physical education futures. London, UK: Routledge, 2010.

KIRK, David. Precarity, critical pedagogy and physical education. New York and London: Routledge, 2020.

KIRK, David; TINNING, Richard. Physical education, curriculum and culture: Critical issues in the contemporary crisis. London: Falmer, 1990.

LEAHY, Deana et al. School health education in changing times. London: Routledge, 2016.

MACDONALD, Doune. Is global neo-liberalism shaping the future of physical education? Physical Education and Sport Pedagogy, v. 19, n. 5, p. 494-499, 2014. doi: 10.1080/17408989.2014.920496

MACDONALD, Doune. Teacher-as-knowledge-broker in a futures-oriented health and physical education. Sport, Education and Society, v. 20, n. 1, p. 27-41, 2015. doi: 10.1080/13573322.2014.935320

MACDONALD, Doune; HAY, Peter; WILLIAMS, Ben. Should you buy? Neo-Liberalism, neo-HPE, and your neo-job. Journal of Physical Education New Zealand, v, 41, n. 3, p. 6-13, 2008.

MCCUAIG, Louise et al. An eroding social justice agenda. Research Quarterly for Exercise and Sport, v. 87, n. 2, p. 151-164, 2016. doi:10.1080/02701367.2016.1163978

PECK, Jamie; TICKELL, Adam. Neoliberalizing space. Antipode, v. 34, n. 3, p. 380-404, 2002.

PENNEY, Dawn; PETRIE, Kirsten; FELLOWS, Sam. HPE in Aotearoa New Zealand: the reconfiguration of policy and pedagogic relations and privatisation of curriculum and pedagogy. Sport, Education and Society, v. 20, n. 1, p. 42-56, 2015. doi: 10.1080/13573322.2014.947566 
POWELL, Darren. Assembling the privatisation of physical education and the 'inexpert' teacher. Sport, Education and Society, v. 20, n. 1, p. 73-88, 2015a. doi: $10.1080 / 13573322.2014 .941796$

POWELL, Darren. 'Part of the solution'?: charities, corporate philanthropy and healthy lifestyles education in New Zealand primary schools. (Doctoral dissertation) - Charles Sturt University, Bathurst, Australia, 2015b.Disponível em: https://researchoutput.csu.edu.au/ws/portalfiles/ portal/9316089/80326 Acesso em: 23 Sept. 2019.

POWELL, Darren. Culture jamming the 'corporate assault' on schools and children. Global Studies of Childhood, v. 8, n. 4, p. 379-391, 2019. doi: $10.1177 / 2043610618814840$

POWELL, Darren. Corporations, schools, and the 'war on childhood obesity': How corporate philanthropy shapes public health and education. London, UK: Routledge, 2020.

POWELL, Darren; GARD, Michael. The governmentality of childhood obesity: Coca-Cola, corporations and schools. Discourse: Studies in the Cultural Politics of Education, v. 36, n. 6, p. 854-867, 2015. doi:10.1080/01596306.2014.905045

PRINGLE, Richard; LARSSON, Hakkan; GERDIN, Göran. Critical Research in sport, health and Physical Education. London: Routledge, 2019.

ROBINSON, Daniel; RANDALL, Lynn. Social justice in physical education: Critical reflections and pedagogies for change. Canada: Canadian Scholars' Press, 2016.

ROWLANDS, Julie; RAWOLLE, Shaun. Neoliberalism is not a theory of everything: A Bourdieuian analysis of illusio in educational research. Critical Studies in Education, v. 54, n. 3, p. 260-272, 2013. doi: https://doi.org/10.1080/17508487.2013.830631

SALTMAN, Kenneth. The gift of education: public education and venture philanthropy. New York: Palgrave MacMillan, 2010.

SALTMAN, Kenneth. Introduction to the first edition. In: SALTMAN, Kenneth; GABBARD, David (Eds). Education as enforcement: The militarization and corporatization of schools. New York: Routledge, 2011. p. 1-18.

SHAMIR, Ronen. The age of responsibilization: on market-embedded morality. Economy and Society, v. 37, n. 1, p. 1-19, 2008. doi: $10.1080 / 03085140701760833$

SPERKA, Leigh. The impact of the outsourcing of Health and Physical Education on curriculum, pedagogy, and assessment. 2018. PhD (Thesis) - School of Human Movement and Nutrition Sciences. University of Queensland, Australia, 2018. Disponível em: https://espace. library.uq.edu.au/view/UQ:559535a Acesso em: 23 sept. 2019.

THORPE, Stephen. Crisis discourse in physical education and the laugh of Michel Foucault. Sport, Education and Society, v. 8, n. 2, p. 131-151, 2003. doi: $10.1080 / 13573320309253$

WILLIAMS, Benjamin; MACDONALD, Doune. Explaining outsourcing in health, sport and physical education. Sport, Education and Society, v. 20, n. 1, p. 57-72, 2014. doi: 10.1080/13573322.2014.914902

WRIGHT, Jan; BURROWS, Lisette; MACDONALD, Doune. Critical inquiry and problemsolving in physical education. London, UK: Routledge, 2004. 